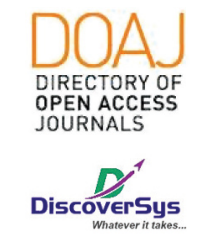

Published by DiscoverSys

\title{
Korelasi kadar laktat dengan Score for Neonatal Acute Physiology Perinatal Extension II (SNAPPE II) pada neonatus yang dirawat di NICU RSUP Sanglah, Bali, Indonesia
}

\author{
I Gede Deden Susma Sugara ${ }^{1 *}$, I Wayan Dharma Artana², Ketut Suarta², Soetjiningsih'², \\ Ni Putu Siadi Purniti ${ }^{2}$, Dyah Kanya Wati ${ }^{2}$, Made Sukmawati ${ }^{2}$, Made Kardana ${ }^{2}$
}

\section{ABSTRACT}

Background: Infant mortality rate is one of the indicators of public health degree that determines the human development index. Various attempts were made to early detect the problems, one of which was by assessing the severity of neonatal disease using Score for Neonatal Acute Physiology Perinatal Extension-II (SNAPPE II) which was associated with lactate levels as a metabolic response and organ dysfunction due to critical illness that were suffered at the Neonatal Intensive Care Unit (NICU).

Methods: A cross-sectional analytic study was conducted among 48 critically ill neonates treated at the Sanglah Hospital Denpasar NICU. Samples were selected from affordable populations by consecutive sampling. Data analysis was performed by SaphiroWilk data normality test, correlation analysis using the Pearson correlation coefficient, significant results if the value of $p<0.05$.
Data were analyzed using SPSS version 17 for Windows.

Results: Most of the respondents were males (67\%), the mean of neonatal gestational age was $33( \pm 3,2)$ weeks with the median neonatal age at lactate sampling being 24 (24-48) hours. The average age of the mother at delivery was 24 (21-40) years. The mean lactate level in critically ill neonatal patients admitted to the NICU was $3.2( \pm 0,5) \mathrm{mmol} / \mathrm{L}$. The mean SNAPPE II score on the subject was 32 (20-42). There was a significant positive correlation between the levels of lactate and the severity of the disease in critically ill neonates in the NICU assessed by SNAPPE II $(r=0.45$; $p=0.004)$.

Conclusion: Lactate levels has a moderate positive correlation with the severity of the disease in critically ill neonates in the NICU assessed by SNAPPE II

Keywords: lactate levels, critically ill neonates, SNAPPE II

Cite This Article: Sugara, I.G.D.S., Artana, I.W.D., Suarta, K., Soetjiningsih., Purniti, N.P.S., Wati, D.K., Sukmawati, M., Kardana, M. 2019. Korelasi kadar laktat dengan Score for Neonatal Acute Physiology Perinatal Extension II (SNAPPE II) pada neonatus yang dirawat di NICU RSUP Sanglah, Bali, Indonesia. Intisari Sains Medis 10 (2): 475-480. D0I: 10.15562/ism.v10i2.505

'Program Pendidikan Dokter Spesialis IImu Kesehatan Anak, Fakultas Kedokteran, Universitas Udayana, RSUP Sanglah, Bali, Indonesia

${ }^{2}$ Departemen IImu Kesehatan Anak, Fakultas Kedokteran, Universitas Udayana, RSUP Sanglah, Bali, Indonesia

\section{*Korespondensi:}

I Gede Deden Susma Sugara; Program Pendidikan Dokter Spesialis IImu Kesehatan Anak, Fakultas Kedokteran, Universitas Udayana, RSUP Sanglah, Bali, Indonesia;

d2n rexsch@yahoo.com

Diterima : 12-04-2019

Disetujui : 30-07-2019

Diterbitkan : 01-08-2019

\section{ABSTRAK}

Latar Belakang: Angka kematian bayi menjadi salah satu indikator derajat kesehatan masyarakat yang menentukan indeks pembangunan manusia. Berbagai upaya dilakukan untuk mendeteksi dini masalah yang dihadapi, salah satunya dengan melakukan penilaian derajat keparahan penyakit neonatus menggunakan Score for Neonatal Acute Physiology Perinatal Extension-II (SNAPPE II) yang dihubungkan dengan kadar laktat sebagai respon metabolisme dan disfungsi organ akibat sakit kritis yang diderita neonatus di Neonatal Intensive Care Unit (NICU).

Metode: Penelitian analitik potong lintang dilakukan terhadap 48 neonatus sakit kritis yang dirawat di NICU RSUP Sanglah Denpasar. Sampel dipilih dari populasi terjangkau dengan cara konsekutif sampling. Analisis data dilakukan dengan uji normalitas data Saphiro-Wilk, analisis korelasi menggunakan koefisien korelasi
Pearson, hasil signifikan bila nilai $p<0,05$. Sampel dianalisis dengan SPSS versi 17 untuk Windows.

Hasil: Sebagian besar responden adalah lelaki (67\%), rerata usia gestasi neonatus adalah $33( \pm 3,2)$ minggu dengan median usia neonatus saat pengambilan sampel laktat adalah 24 (24-48) jam. Rerata kadar laktat pada pasien neonatus dengan sakit kritis yang dirawat di NICU adalah $3.2( \pm 0,5) \mathrm{mmol} / \mathrm{L}$. Median skor SNAPPE II pada subjek adalah 32 (20-42). Terdapat korelasi positif sedang yang bermakna antara kadar laktat dengan derajat keparahan penyakit pada neonatus sakit kritis di NICU yang dinilai dengan SNAPPE III $(r=0,45 ; p=0,004)$.

Simpulan: kadar laktat memiliki korelasi positif sedang terhadap derajat keparahan penyakit pada neonatus sakit kritis di NICU yang dinilai dengan SNAPPE II
Kata kunci: kadar laktat, neonatus sakit kritis, SNAPPE II

Site Pasal ini: Sugara, I.G.D.S., Artana, I.W.D., Suarta, K., Soetjiningsih., Purniti, N.P.S., Wati, D.K., Sukmawati, M., Kardana, M. 2019. Korelasi kadar laktat dengan Score for Neonatal Acute Physiology Perinatal Extension II (SNAPPE II) pada neonatus yang dirawat di NICU RSUP Sanglah, Bali, Indonesia. Intisari Sains Medis 10 (2): 475-480. D0I: 10.15562/ism.v10i2.505 


\section{PENDAHULUAN}

Angka kematian bayi menjadi salah satu indikator derajat kesehatan masyarakat yang menentukan indeks pembangunan manusia dan kematian pada neonatus merupakan penyumbang terbesar angka kematian bayi. Angka kematian neonatus mencapai empat juta setiap tahun, terutama pada kehidupan minggu pertama sekitar $75 \%$ berdasarkan perkiraan World Health Organization (WHO). ${ }^{1}$ Penyebab kematian neonatus terbanyak yaitu dari komplikasi kelahiran kurang bulan, komplikasi dengan proses persalinan, dan sepsis. ${ }^{2}$ Angka kejadian infeksi berat yang mengakibatkan sepsis pada neonatus terjadi di negara berkembang sekitar 1,8 sampai 18 per 1000 kelahiran hidup. ${ }^{2}$ Berdasarkan data Depkes tahun 2015 penyebab kematian bayi baru lahir yaitu berat bayi lahir rendah (BBLR) dan asfiksia berkontribusi dalam angka Kematian Bayi (AKB) di Indonesia sebanyak 34 per 1000 kelahiran hidup. ${ }^{3}$ Terjadi peningkatan $\mathrm{AKB}$ walaupun tidak signifikan antara tahun 2012 dengan tahun 2013 yaitu dari 5,09 per 1000 kelahiran hidup menjadi 5,5 per 1000 kelahiran hidup. Laporan bagian Neonatologi Ilmu Kesehatan Anak, Fakultas Kedokteran Universitas Udayana/RSUP Sanglah Denpasar tahun 2009 menyebutkan bahwa kematian neonatus terbanyak karena kegawatan neonatus terutama pada pernapasan yaitu $42,7 \%$, sepsis $(17,6 \%)$, bayi berat lahir rendah (9,4\%), dan sisanya penyebab lain dari 159 neonatus yang meninggal. ${ }^{4}$

Neonatus dengan sakit kritis adalah berbagai proses penyakit yang menyebabkan instabilitas fisiologis sampai dapat menyebabkan kecacatan dan potensi mengancam nyawa dalam hitungan menit sampai jam. Indikasi perawatan intensif berupa adanya kelainan atau kondisi neonatus seperti anemia, apnea, bradikardia, hidrosefalus, perdarahan intrakranial, hiperbilirubinemia, enterokolitis nekrotikan, patent ductus artiriosus (PDA), gawat napas, dan asfiksia berat. ${ }^{5}$

Penilaian derajat keparahan penyakit dapat dilakukan dengan deteksi dini segera setelah dirawat. Sistem skoring derajat keparahan penyakit neonatus yang baik adalah mampu menduga morbiditas dan mortalitas neonatus. Sistem skoring yang sangat baik untuk menduga mortalitas dan morbiditas pada neonatus yang dirawat di NICU berdasarkan beberapa penelitian yaitu SNAPPE II. Score for Neonatal Acute Physiology Perinatal Extension-II (SNAPPE II) merupakan sistem skoring hasil revisi dari Score for Neonatal Acute Physiology (SNAP) /Score for Neonatal Acute Physiology Perinatal Extension (SNAPPE). ${ }^{6}$ Penelitian oleh Richardson dkk memperhitungkan berat lahir, usia kehamilan, dan nilai APGAR dalam mengembangkan SNAP, sehingga dihasilkanlah SNAPPE. $^{7}$ Kesulitan pengumpulan data untuk 30 parameter dan kadangkadang tidak lengkap, sehingga nilai total skor sulit diperoleh. Hal ini merupakan keterbatasan SNAP dan SNAPPE. Kemudian SNAP/SNAPPE disederhanakan menjadi 9 variabel dan versi terbaru ini menghasilkan SNAPPE II. ${ }^{7}$

Respon metabolisme dan fungsi organ juga dipertimbangkan sebagai faktor yang memengaruhi derajat keparahan penyakit. Permasalahan terhadap neonatus sakit kritis yang dirawat di ruang terapi intensif sering melibatkan kegagalan berbagai macam organ yang erat kaitannya dengan penyakit yang mendasari ataupun komplikasi yang ditimbulkan. ${ }^{8}$ Hal ini dapat memicu terjadinya hipoksia pada jaringan sehingga menyebabkan terjadinya perubahan metabolisme dalam sel. Perubahan metabolisme sel karena keadaan hipoksia tersebut menyebabkan terjadinya metabolisme anaerob yang berujung pada produksi zat sisa yakni berupa laktat. Berbagai penelitian menunjukkan bahwa terdapat hubungan antara hipoksia jaringan dengan produksi laktat yang disebabkan oleh penurunan komponen penghantar oksigen sistemik (seperti hemoglobin, saturasi oksigen, dan curah jantung), sehingga keadaan hipoksia yang dihasilkan oleh berbagai macam kondisi medis secara langsung berkontribusi pada tingginya produksi laktat dalam darah. ${ }^{8}$ Penelitian yang dilakukan oleh Marecaux dkk menunjukkan bahwa laktat dihubungkan dengan marker lainnya mempunyai nilai prognosis yang lebih baik dibandingkan dengan Tumor Necrosis Factor (TNF) dan Interleukin-6 (IL-6). ${ }^{9}$ Hussain dkk menemukan bahwa hiperlaktatemia dapat mengindikasikan kematian pada saat masuk rumah sakit (MRS) apabila hiperlaktatemia bertahan setelah 24 jam pengobatan. ${ }^{10}$

Hasil pencarian terhadap penelitian yang bertujuan mencari hubungan korelasi antara kadar laktat pada neonatus dengan SNAPPE II belum pernah dilakukan di Indonesia. Berdasarkan permasalahan yang dipaparkan pada data di atas, maka peneliti bertujuan untuk mengetahui hubungan antara kadar latkat terhadap derajat keparahan penyakit berdasarkan SNAPPE II.

\section{METODE PENELITIAN}

Desain penelitian yang digunakan adalah studi potong lintang yang dilakukan di NICU RSUP Sanglah Denpasar Bali terhadap 38 neonatus kritis dengan menggunakan teknik konsekutif. Waktu penelitian dimulai dari bulan Desember 2017Mei 2018. Pemeriksaan sampel darah dilakukan di tempat (bed side test). Adapun beberapa kriteria inklusi dalam penelitian ini adalah: 1) Neonatus dengan sakit kritis yang dirawat di 
NICU RSUP Sanglah dan 2) Orang tua menyetujui mengikutsertakan anaknya dalam penelitian ini dan bersedia menandatangani lembar persetujuan setelah penjelasan.

Variabel penelitian pada penelitian ini adalah umur bayi, neonatus sakit kritis, kadar laktat, nilai SNAPPE II, suhu tubuh, rasio $\mathrm{PaO} 2 / \mathrm{FiO}$, pH serum, berat badan lahir, nilai APGAR, cara persalinan,dan usia ibu saat melahirkan.Bahan yang dipergunakan dalam penelitian adalah sampel darah $\mathrm{k}$ apiler yang diambil dari tumit peserta penelitian dengan menggunakan alat pemeriksa kadar laktat darah portable (hand held analyser).

Tabel 1. Karakteristik subjek penelitian

\begin{tabular}{|c|c|}
\hline Karakteristik & Jumlah ( $n=48)$ \\
\hline \multicolumn{2}{|l|}{ Jenis kelamin } \\
\hline Lelaki, n (\%) & $32(67)$ \\
\hline Usia neonatus, jam, median (min-max) & $24(24-48)$ \\
\hline Usia ibu, tahun, median (min-max) & $24(21-40)$ \\
\hline Usia gestasi, minggu, rerata $( \pm \mathrm{SB})$ & $33( \pm 3,2)$ \\
\hline Term baby, n (\%) & $5(10)$ \\
\hline Moderate to late preterm, n (\%) & $24(50)$ \\
\hline Very preterm, n (\%) & $19(40)$ \\
\hline Extremely preterm, n (\%) & 0 \\
\hline \multicolumn{2}{|l|}{ Cara persalinan, } \\
\hline Spontan, $\mathrm{n}(\%)$ & $9(19)$ \\
\hline Seksio sesaria, n (\%) & $39(81)$ \\
\hline Berat lahir bayi, gram, median (min-max) & $1800(1000-3800)$ \\
\hline Berat Bayi Normal, n (\%) & $14(29)$ \\
\hline BBLR, n (\%) & $18(38)$ \\
\hline BBLSR, n (\%) & $15(31)$ \\
\hline BBLASR, n(\%) & $1(2)$ \\
\hline Panjang lahir bayi, cm, median (min-max) & $40,5(33-51)$ \\
\hline \multicolumn{2}{|l|}{ Berat badan sesuai usia gestasi } \\
\hline Sesuai Masa Kehamilan, n(\%) & $45(94)$ \\
\hline Kecil Masa Kehamilan, n (\%) & $3(6)$ \\
\hline Besar Masa Kehamilan, n (\%) & 0 \\
\hline Skor APGAR menit ke-5, median (min-max) & $4(3-9)$ \\
\hline$\geq 7, \mathrm{n}(\%)$ & $3(6)$ \\
\hline$<7, \mathrm{n}(\%)$ & $45(94)$ \\
\hline \multicolumn{2}{|l|}{ Tekanan arteri } \\
\hline Tekanan sistolik, mmHg, median (min-max) & $40(35-48)$ \\
\hline Tekanan diastolik, mmHg, median (min-max) & $22(20-29)$ \\
\hline Suhu tubuh aksila, ${ }^{\circ} \mathrm{C}$, median $(\min -\max )$ & $36,8(36,4-37,7)$ \\
\hline Produksi urin, ml/kg/jam, median (min-max) & $2,8(1,3-3,75)$ \\
\hline Kejang multiple, n (\%) & $1(2)$ \\
\hline \multicolumn{2}{|l|}{ Analisis gas darah } \\
\hline pH serum, median (min-max) & $7,3(7,2-7,6)$ \\
\hline $\mathrm{PaCO}_{2}, \mathrm{mmHg}$, median (min-max) & $52,5(23-90)$ \\
\hline $\mathrm{PaO}_{2}, \mathrm{mmHg}$, median (min-max) & $98,2(26,8-185,2)$ \\
\hline $\mathrm{HCO}_{3}, \mathrm{mmol} / \mathrm{L}$, rerata $( \pm \mathrm{SB})$ & $25,2( \pm 4,0)$ \\
\hline Be, mmol/L, median (min-max) & $1,6(-6,8-8,8)$ \\
\hline Rasio $\mathrm{PaO} 2 / \mathrm{FiO} 2$, rerata $( \pm \mathrm{SB})$ & $4,66( \pm 2,12)$ \\
\hline
\end{tabular}

IQR: interquartile range, $\mathrm{SB}$ : simpang baku, $\mathrm{n}$ : jumlah
Alat yang digunakan untuk pemeriksaan laktat adalah Accutrend plus ${ }^{\ominus}$ (Roche Diagnostics, Mannheim,Germany). Instrumen lain yang digunakan dalam penelitian ini adalah lembar persetujuan setelah penjelasan, lembar kuesioner untuk mengumpulkan data subjek, dan lembar sistem skoring (SNAPPE II).

Penelitian dilakukan melalui beberapa tahap yaitu tahap awal pengurusan etik pada Komite Etika Penelitian Fakultas Kedokteran Universitas Udayana dan pengurusan ijin oleh Rumah Sakit Umum Pusat Sanglah Denpasar, dilanjutkan dengan tahap pengumpulan data. Pemeriksaan kadar laktat darah dilakukan dengan menggunakan alat pemeriksa kadar laktat darah portable (hand held analyser). Alat yang digunakan adalah Accutrend plus ${ }^{\otimes}$ (Roche Diagnostics, Mannheim, Germany), suatu alat yang berukuran kecil dengan sumber tenaga baterai dan merupakan reflectance photometry. Alat ini menggunakan strip tes yang ditetesi dengan sampel darah. Dalam strip, sel darah merah akan bergerak melewati fiber glass filter sebelum mencapai lapisan reaksi yang mengandung lactate oxidase. Penilaian SNAPPE II dilihat dari lembar pemantauan pasien di ruang NICU serta rekam medis pasien. Penilaian dilakukan dalam 24 jam pertama pasien dirawat di NICU. Hasil pemeriksaan dinilai berdasarkan skor yang telah ditentukan pada setiap klasifikasi variabel kemudian skor seluruh variabel dijumlahkan. Total skor yang didapat adalah nilai SNAPPE II yang dimasukkan ke data pasien.

Data yang diperoleh dianalisis dengan mempergunakan program SPSS versi 17 untuk windows dengan langkah-langkah sebagai berikut: 1) Uji normalitas menggunakan ShapiroWilk oleh karena didapatkan jumlah sampel dibawah 50;2) Analisis deskriptif bertujuan untuk menggambarkan karakteristik sampel penelitian dan variabel yang diteliti. Variabel yang berskala data numerik ditampilkan dalam bentuk rerata (SB) atau median disertai nilai minimal dan maksimal. Variabel yang berskala data kategorikal ditampilkan dalam bentuk frekuensi relatif (jumlah dan persen); 3) Uji korelasi antara kadar laktat dan nilai SNAPPE II menggunakan Spearman karena distribusi tidak normal.

\section{HASIL PENELITIAN}

Karakteristik dari 48 subjek penelitian ini didapatkan subjek lelaki sebanyak 32 (67\%) dan 16 subjek perempuan (33\%). Rerata usia gestasi neonatus adalah 33 (3) minggu dengan median usia neonatus saat pengambilan sampel laktat adalah 24 (24-48) jam. Sebanyak 18 (38\%) kelahiran termasuk BBLR, 15 (31\%) BBLSR, dan 1 (2\%) BBLASR dengan median berat lahir bayi yaitu 1800 
Tabel 2. Uji normalitas kadar laktat dan nilai SNAPPE II

\begin{tabular}{lcc}
\hline \multicolumn{1}{c}{ Parameter } & Nilai & P \\
\hline Kadar laktat, rerata $( \pm$ SB) & $3,15( \pm 0,5)$ & 0,09 \\
SNAPPE II, median (min-max) & $32(20-42)$ & 0,001 \\
\hline
\end{tabular}

Uji normalitas menggunakan Saphiro-Wilk; P: bermakna apabila $<0,05$

Tabel 3. Analisis korelasi Spearman kadar laktat serum dengan SNAPPE II

\begin{tabular}{rcc}
\hline Parameter & & SNAPPE II \\
\hline Kadar laktat & $\mathrm{r}$ & 0,45 \\
& $\mathrm{P}$ & 0,004 \\
\hline
\end{tabular}

r: koefisien korelasi; P: bermakna apabila $<0,05$

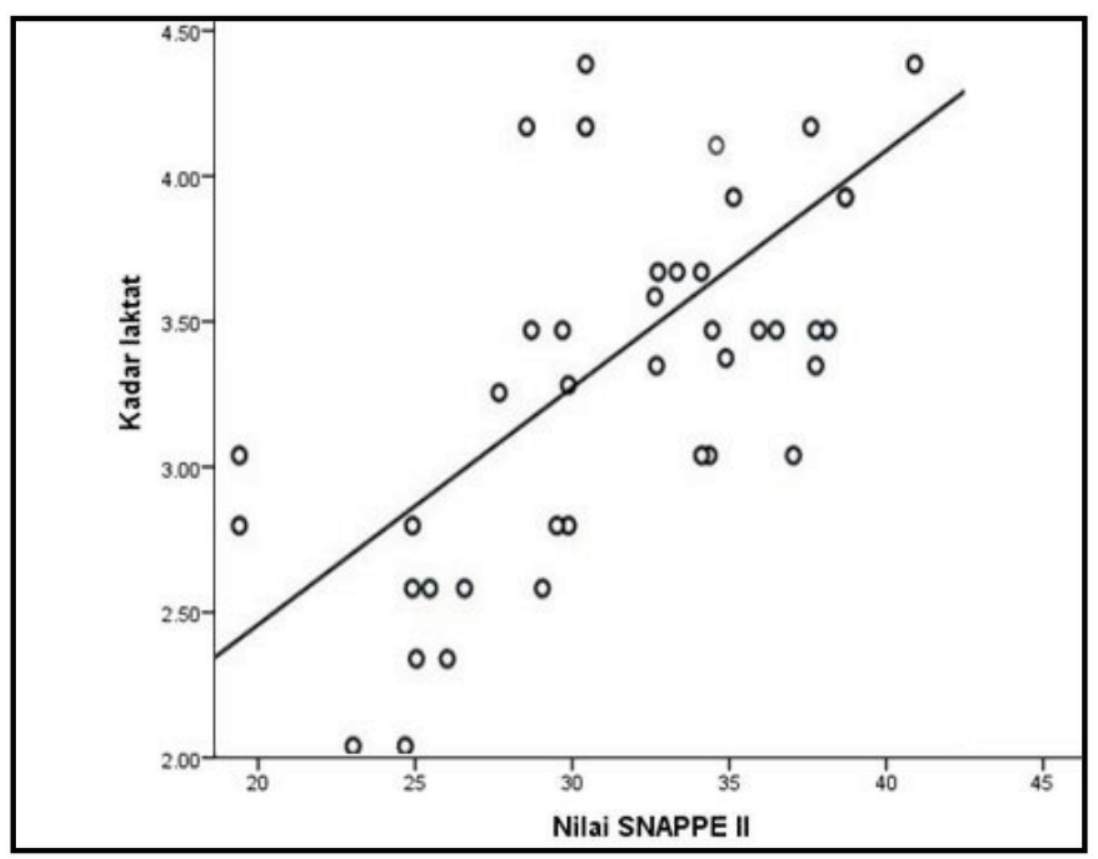

Gambar 1. Grafik scatter plot korelasi kadar laktat dengan SNAPPE II

(1000-3800) gram. Median usia ibu saat melahirkan adalah 24 (21-40) tahun. Tabel 1 menunjukkan karakteristik subjek penelitian.

Berdasarkan uji normalitas Shapiro-Wilk, data SNAPPE II berdistribusi tidak normal dan kadar laktat adalah normal (Tabel 2). Nilai rerata kadar laktat serum neonatus sakit kritis di NICU adalah $3.15(0,5) \mathrm{mmol} / \mathrm{L}$. Median skor SNAPPE II pada subjek adalah 32 (20-42). Analisis korelasi Spearman, didapatkan korelasi positif sedang yang bermakna antara kadar laktat dengan derajat keparahan penyakit pada neonatus sakit kritis di NICU yang dinilai dengan SNAPPE II $(r=0,45$; $\mathrm{p}=0,004$ ) (Tabel 3, Gambar 1). Hal ini berarti semakin tinggi kadar laktat maka derajat keparahan penyakit neonatus semakin meningkat.

\section{PEMBAHASAN}

Neonatal Intensif Care Unit (NICU) merupakan ruang perawatan untuk neonatus yang berisiko tinggi mengalami morbiditas dan mortalitas. Derajat sakit yang dialami neonatus di NICU bervariasi dan dipengaruhi oleh banyak faktor. Pada penelitian ini neonatus lelaki yang diikutkan dalam penelitian yaitu $32(67 \%)$ orang. Jenis kelamin tidak berhubungan dengan derajat berat sakit neonatus yang berisiko menimbulkan kematian. Derajat berat sakit neonatus lebih ditentukan karena ketidakstabilan fisiologi neonatus saat masih dalam kandungan maupun setelah lahir. ${ }^{11}$ Kadar laktat juga tidak berbeda signifikan pada neonatus lelaki dan perempuan di NICU. ${ }^{12}$

Median usia ibu pada penelitian ini adalah 24 (21-40) tahun. Usia ibu saat melahirkan dapat memengaruhi luaran bayi yang dilahirkan. Kejadian morbiditas dan mortalitas peritanal meningkat pada usia ibu $>35$ tahun. Sedangkan studi terdahulu menunjukkan bahwa kadar laktat didapatkan tidak berbeda bermakna pada kelompok usia ibu. ${ }^{13}$ Pada penelitian ini didapatkan dengan berat lahir bayi yang beragam, yang kemudian dibedakan menjadi BBLR sejumlah 38\%, BBLSR sejumlah $31 \%$ dan BBLASR sejumlah $2 \%$. Penelitian yang dilakukan di Australia mendapatkan angka kejadian kematian di NICU yaitu 31,3\% untuk neonatus dengan berat lahir 1000 sampai 1500 gram, sedangkan kematian neonatus dengan berat lahir $<1000$ gram mencapai $63,1 \% .^{14}$

Pada penelitian ini sejumlah $81 \%$ cara persalinan dengan seksio sesaria karena indikasi ibu ataupun janin. Fisiologi persalinan seksio sesaria berbeda dengan persalinan spontan. Komplikasi dikatakan lebih banyak terjadi pada seksio sesaria. Persalinan seksio sesaria dilaporkan meningkatkan kebutuhan akan NICU karena persalinan atas indikasi janin. Hal ini menunjukkan kemungkinan adanya kegawatan janin sejak dalam rahim yang dapat memengaruhi prognosis neonates. ${ }^{15}$ Sedangkan studi yang dilakukan oleh Deshpande melaporkan bahwa laktat pada bayi kurang bulan di NICU tidak dipengaruhi cara persalinan. ${ }^{8}$

Karakteristik subjek pada penelitian ini menggunakan skor Apgar bayi pada menit ke-5. Bayi lahir dengan skor Apgar menit ke-5 $<7$ sejumlah 45 (94\%) bayi. Skor Apgar menunjukkan kondisi segera pada bayi baru lahir dan apabila dilakukan secara benar dapat dijadikan pertimbangan dalam penilaian bayi. Rendahnya skor Apgar pada menit ke-5 memiliki hubungan dengan mortalitas bayi. Risiko kelainan neurologi pada bayi dikatakan meningkat pada bayi dengan skor Apgar yang rendah pada menit ke-5. ${ }^{16,17}$

Penelitian ini mendapatkan rerata kadar laktat 
pada pasien neonatus dengan sakit kritis yang dirawat di NICU adalah 3,15 $(0,5) \mathrm{mmol} / \mathrm{L}$. Kadar laktat meningkat dalam keadaan hipoperfusi dan disfungsi organ. Hal ini sesuai dengan penelitian Koliski dkk yang mendapatkan kadar rerata laktat pada pasien kritis sebanyak 3,3 $\mathrm{mmol} / \mathrm{L}^{18}$ Penelitian serupa oleh Fernandez dkk menyatakan konsentrasi laktat plasma $>4,2 \mathrm{mmol} / \mathrm{L}$ pada 6 jam kehidupan dikorelasikan dengan kematian neonatal selama 3 hari pertama kehidupan. ${ }^{19}$ Laktat sudah diteliti sebagai salah satu penanda biokimiawi hipoksia jaringan pada pasien dengan sakit kritis dan sepsis. Analisis laktat darah dapat memberikan informasi dalam penilaian neonatus setelah kelahiran. Asidemia metabolik akan terjadi pada neonatus bila terjadi kekurangan ketersediaan oksigen yang memicu munculnya pembakaran anaerob. Kadar laktat yang tinggi dapat merusak organ-organ tubuh. ${ }^{20}$

Sistem skoring SNAPPE II sangat baik untuk menduga kematian pada neonatus secara bermakna. Median SNAPPE II pada penelitian ini didapatkan 32 (20-42). Hal ini didukung oleh penelitian oleh Mia dkk di Surabaya yang mendapatkan median SNAPPE II adalah 30 dengan sensitivitas $81,8 \%$ dan spesifisitas 76,9\%. ${ }^{21}$ Sedangkan studi oleh Aryana dkk yang dilakukan di NICU RSUP Sanglah juga mendapatkan median SNAPPE II pada kelompok yang meninggal lebih tinggi yaitu 37 dibandingkan dengan median pada kelompok yang hidup yaitu 23. ${ }^{4}$ Penelitian yang dilakukan di India juga mendapatkan hasil yang sama, SNAPPE II pada kelompok yang meninggal adalah 45,72 $\pm 18,68$ dan kelompok yang bertahan hidup adalah $21,04 \pm 15,41 .^{2}$

Semakin kecil usia kehamilan maka kematian akan semakin tinggi, terutama pada kelompok usia kehamilan <37 minggu. Beberapa hal yang mungkin menjadi penyebabnya yaitu: (1) infeksi saluran genital ibu sebagai penyebab utama persalinan prematur, (2) frekuensi infeksi intraamnion berbanding terbalik dengan usia kehamilan, (3) neonatus prematur mempunyai respons imun yang belum matang, dan juga (4) neonatus prematur sering memerlukan pemasangan akses vena yang lebih lama, intubasi endotrakea, atau prosedur invasif lainnya yang menjadi tempat masuknya kuman atau gangguan mekanisme pertahanan tubuhnya, baik mekanis maupun imunologis. ${ }^{22}$ Pada penelitian ini didapatkan median skor SNAPPE II yaitu 32 (20-42), yang menunjukkan semakin besar skor yang diperoleh semakin besar kemungkinan mengalami kematian. Probabilitas untuk mengalami perburukan dan kematian 0.5 ditentukan sebagai titik potong SNAPPE II berdasarkan kemungkinan mengalami prognosis buruk semakin besar. ${ }^{2}$

Penelitian ini memperlihatkan adanya hubungan antara kejadian hiperlaktatemia dengan kejadian meninggal pada penderita penyakit kritis. Keadaan hiperlaktatemia baru akan terjadi pada hipoperfusi jaringan yang berat, mengindikasikan beratnya kondisi yang mendasari terjadinya peningkatan laktat serta progresivitas dari penyakit dasar. ${ }^{23}$ Keadaan hiperlaktatemia melibatkan peningkatan produksi dan atau penurunan kemampuan pengeluaran laktat. Hal ini dapat menyebabkan gangguan mikrosirkulasi, kerusakan mitokondria, dan atau gangguan sistem respirasi sel. Kadar laktat yang sangat tinggi atau hiperlaktatemia yang menetap mencerminkan stres mitokondria yang berat yang mengakibatkan disfungsi sel yang luas serta kegagalan organ. ${ }^{23}$

Pada penelitian ini berbagai karakteristik sampel yang dapat meningkatkan kadar laktat, tidak menunjukkan peranannya terhadap luaran melalui kadar laktat. Hal ini berarti apapun penyebabnya, peningkatan kadar laktat darah kapiler secara independen memberikan pengaruh yang kuat terhadap metabolisme sel dan jaringan yang dapat berakhir dengan kematian sel. Reaksi normal menunjukkan kadar laktat yang lebih tinggi dengan meningkatnya keparahan sakit. Hal ini tampak jelas pada populasi anak dan dewasa yang mengalami sakit kritis. Penelitian ini belum dapat menjawab apakah bayi mengalami sakit kritis karena hipoksia jaringan berat atau progresivitas dari penyakit dasar sebagai akibat sakit kritis. ${ }^{24}$ Meskipun penelitian ini telah memberikan hasil yang serupa dengan studi terdahulu, namun penulis merasa masih terdapat kelemahan penelitian. Penelitian ini memiliki kelemahan yaitu hubungan sebab akibat antara kedua variabel belum dapat dijelaskan karena penelitian ini merupakan penelitian awal untuk mengetahui adanya korelasi antara kadar laktat dengan derajat keparahan penyakit pada neonatus sakit kritis. Pemeriksaan kadar laktat dilakukan serial dalam 24 jam sehingga dapat menentukan kemajuan resusitasi, terapi, dan luaran.

\section{SIMPULAN}

Hasil penelitian ini dapat disimpulkan rerata kadar laktat pada neonatus sakit kritis yang dirawat di NICU adalah $3.2(0.5) \mathrm{mmol} / \mathrm{L}$ serta median skor SNAPPE II yaitu 32 (20-42). Terdapat hubungan positif sedang bermakna antara kadar laktat dengan skor SNAPPE II pada neonatus sakit kritis di NICU.

\section{ETIKA PENELITIAN}

Penelitian ini dilaksanakan berdasarkan kelaikan etik penelitian dari Komite Etik Fakultas 
Kedokteran Unud/RSUP Sanglah Denpasar No. 1626/UN.14.2.2/KEP/2017 dan telah mendapat ijin dari RSUP Sanglah dengan No.LB.02.01/ IXIV.2.2.1/2017.

\section{KONFLIK KEPENTINGAN}

Penulis menyatakan bahwa tidak terdapat konflik kepentingan dalam penulisan laporan hasil penelitian ini

\section{PENDANAAN}

Penulis bertanggung jawab terhadap pendanaan studi ini tanpa melibatkan pihak sponsor, grant, atau sumber pendanaan lainnya

\section{KONTRIBUSI PENULIS}

Seluruh penulis memiliki kontribusi yang sama baik dalam tahap penyusunan proposal penelitian, kerangka konsep, pengambilan sampel, analisis data, hingga interpretasi data penelitian dalam bentuk artikel penelitian

\section{DAFTAR PUSTAKA}

1. World Health Organization. Neonatal mortality: situation and trends. Global Health Observatory Data. 2016. [Available at: https://www.who.int/gho/child_health/ mortality/neonatal_text/en/] [Accessed on January $1^{\text {st }}$ 2019]

2. Harsha SS, Archana BR. SNAPPE-II (Score for Neonatal Acute Physiology with Perinatal Extension-II) in Predicting Mortality and Morbidity in NICU. J Clin Diagn Res. 2015;9(10):SC10-2.

3. Abdullah A, Hort K, Butu Y, Simpson L. Risk factors associated with neonatal deaths: a matched case-control study in Indonesia. Glob Health Action. 2016;9:30445

4. Aryana GK, Kardana M, Adiputra N. Peranan Score for Neonatal Acute Physiology Perinatal Extension II (SNAPPE II) sebagai Alat Duga Kematian Neonatus. Jurnal Perinasia. 2016;6:102-07.

5. Suradi R. Pemeriksaan Fisis pada Bayi Baru Lahir. Dalam: Kosim MS, Yunanto A, Dewi R, Sarosa GI, Usman A. Penyunting: Buku Ajar Neonatologi, edisi pertama. Jakarta: BP IDAI. 2008:71-88.

6. Groenendaal F, de Vos MC, Derks JB, Mulder EJH. Improved SNAPPE-II and CRIB II scores over a 15-year period. J Perinatol. 2017;37(5):547-551.

7. Richardson DK, Gray JE, McCormick MC, Daniels KW, Goldmann DA. Score for Neonatal Acute Physiology: Aphysiologic Severity Index for Neonatal Intensive Care. Pediatrics, 1993;91(3):617-623.

8. Deshpande SA, Platt MP. Association Between Blood Lactate and acid-base Status and Mortality in Ventilated Babies. Arch Dis Chil Fetal Neonatal. 1997;76(1):F15-20.
9. Marecaux G, Pinsky MR, Dupont E, Kahn RJ, Vincent JL. Blood lactate levels are better prognostic indicators than TNF and IL-6 levels in patient with septic shock. Intensive Care Med. 1996;22(5):404-8.

10. Hussain F, Gilshenan K, Gray PH. Does lactate in the first 12 hours of life predict mortality in extremely premature infants?. J Paediatr Child Health. 2009;45(5):263-7.

11. Dorling JS, Field DJ, Manktelow B. Neonatal disease severity scoring systems. Arch Dis Child. 2005;90(1):F1116.

12. Nadeem M, Clarce A, Demsdey EM. Day one serum lactate values in preterm infant less than 32 weeks gestation. Eur Jr Pediatr. 2010;169(6):667-70.

13. Gladden LB. Lactate metabolism: a new paradigm for the third millennium. J Physiol. 2004;558(1):5-30.

14. Nichol A, Bailey M, Egi M, Petilla V, French C, Stachowski E. Dynamic lactate indices as predictors of outcome in critically ill patients. Crit Care. 2011;15(5):R242.

15. Butsashvili M, Kourbatova E, Macharashvili N, Kamkamidze G, McNutt LA, DeHovitz J, et al. Risk Factors of Mortality in Septic Newborns in Neonatal Intensive Care Units (NICUs) in Tbilisi, the Republic of Georgia. Eur J Epidemiol. 2009;24(8):477-479.

16. Lee SW, Hong YS, Park DW, Choi SH, Moon SW, Park JS, et al. Lactic acidosis not hyperlactatemia as a predictor of in hospital mortality in septic emergency patients. Emerg Med J. 2008;25(10):659-65.

17. American Academy of Pediatrics Committee on Fetus and Newborn. The Apgar Score. Pediatrics. 2015;136(4):819822.

18. Koliski A, Cat I, Giraldi DJ, Cat ML. Blood lactate concentration as prognostic marker in critically ill children. J Pediatr, (Rio J). 2005;81(4):287-92.

19. Fernandez HGC, Vieira AA, Barbosa ADM. The correlation between plasma lactate concentrations and early neonatal mortality. Rev Bras Ter Intensiva. 2012;24(2):184-187.

20. Tuten A, Dincer E, Topcuoglu S, Sancak S, Akar S, Hakyemez Toptan $\mathrm{H}$, et al. Serum lactate levels and perfusion index: are these prognostic factors on mortality and morbidity in very low-birth weight infants? J Matern Fetal Neonatal Med. 2017;30(9):1092-1095

21. Mia RA, Etika R, Harianto A, Indarso F, Damanik SM. The Use of Score for Neonatal Physiology Perinatal Extention II (SNAPPE II) in Predicting Neonatal Outcome in Neonatal Intensive Care Unit. Paediatrica Indonesiana. 2005;45(6):241-245.

22. Richardson DK, Corcoran JD, Escobar GJ, Lee SK. SNAP-II and SNAPPE-II: Simplified Newborn Illness Severity and Mortality Risk Scores. J Pediatr. 2001;138(1):92-100.

23. Haas SA, Lange T, Saugel B, Petzoldt M, Fuhrmann V,MetschkeM,etal.Severehyperlactatemia,lactateclearance and mortality in unselected critically ill patients. Intensive Care Med. 2016;42(2):202-10.

24. Nguyen B, Loomba M, Yang J, Jacobsen G, Shah K, Otero RM, et al. Early lactate clearance is associated with biomarkers of inflammation, coagulation, apoptosis, organ dysfunction and mortality in severe sepsis and septic shock. J Inflamm (Lond). 2010;7:6.

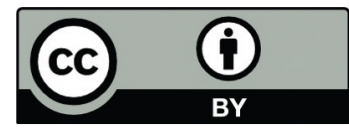

This work is licensed under a Creative Commons Attribution 